\title{
Two new species of biting midges of the genus Culicoides (Diptera: Ceratopogonidae) from northernmost Honshu, Japan
}

\author{
Shigeo KITAOKA* \\ Niigata Sangyo University, Kashiwazaki 945-13, Japan
}

(Received: March 12, 1991)

\begin{abstract}
Key words: Ceratopogonidae, Culicoides aomoriensis sp. n., C. tatebeae sp. n., taxonomy, Aomori Prefecture.
\end{abstract}

Abstract: Two new species of Culicoides biting midges, $C$. aomoriensis and C. tatebeae, are described and figured from the material collected during a survey of biting midges in Aomori Prefecture, Japan.

\section{INTRODUCTION}

The first data on the species of Culicoides in the northern district of Honshu were reported by Okada (1941), which included the descriptions of $C$. humeralis, $C$. sitinohensis, C. towadenis and C. tohokuensis. Recently, Tatebe et al. (1989) made a comprehensive survey of Culicoides fauna at 12 different places in Aomori Prefecture, manifesting the seasonal prevalences of main species by totally 184 light-trap collections in 1986 and 1987. Very recently, Wada (1990) reported a review on the verbosus group in the genus Culicoides, which included the descriptions of $C$. fukudai and C. tsutaensis collected in the same prefecture. The specimens from the Shimokita Peninsula included two new species, therefore, they are described in this paper. Measurements in the text are micrometers.

The holotypes of the new species are deposited in the National Science Museum (Natural History), Tokyo.

* 北岡茂男：新潟産業大学（宁945-13 柏崎市軽井川 4730)
Description

\section{Culicoides aomoriensis sp. $n$.}

Female (Fig. 1A-D).

Body: Brown, large.

Head: Eyes contiguous for two facets, bare (Fig. 1B). Antenna with flagellar segments in proportion ( $\mu \mathrm{m}$ units) of 48-38-4043-43-44-46-46-65-66-71-77-110, total length in two females 727 and 826, AR 1.09 and 1.12 , respectively; sensilla coeloconica on segments 3,11-15, number of sensilla 2, 1, 1, 1,2 , 2. Palpal segments (Fig. 1C) in proportion $(\mu \mathrm{m})$ of 26-76-90-32-36, PR 3.2; third segment slightly swollen, spindle-shaped, with scattered sensilla on distal half; second with almost the same width as third. Mouthparts long, $\mathrm{P} / \mathrm{H}$ ratio 0.86 ; mandible with 14 or 15 teeth.

Thorax: Brown, mesonotum with a submedian pair of prominent, large, yellowish brown patches and with similar areas on lateral margins; scutellum with a pair each of mid-scutellar and lateral bristles. Legs: Brown, fore and mid-knee yellowish; base and apex of hind tibia yellowish; hind tibial 


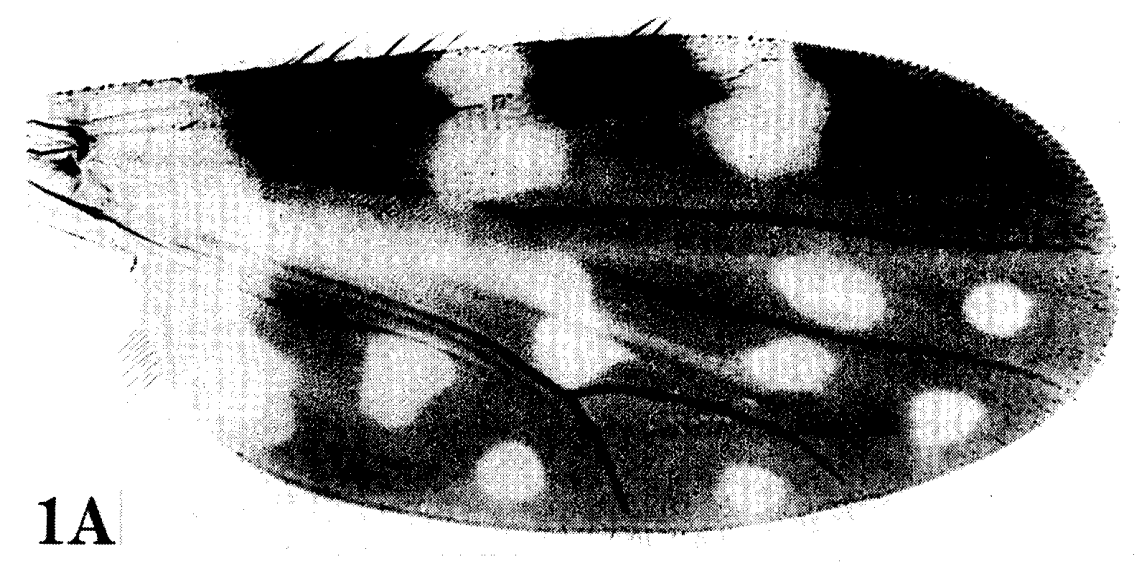

$2 A$
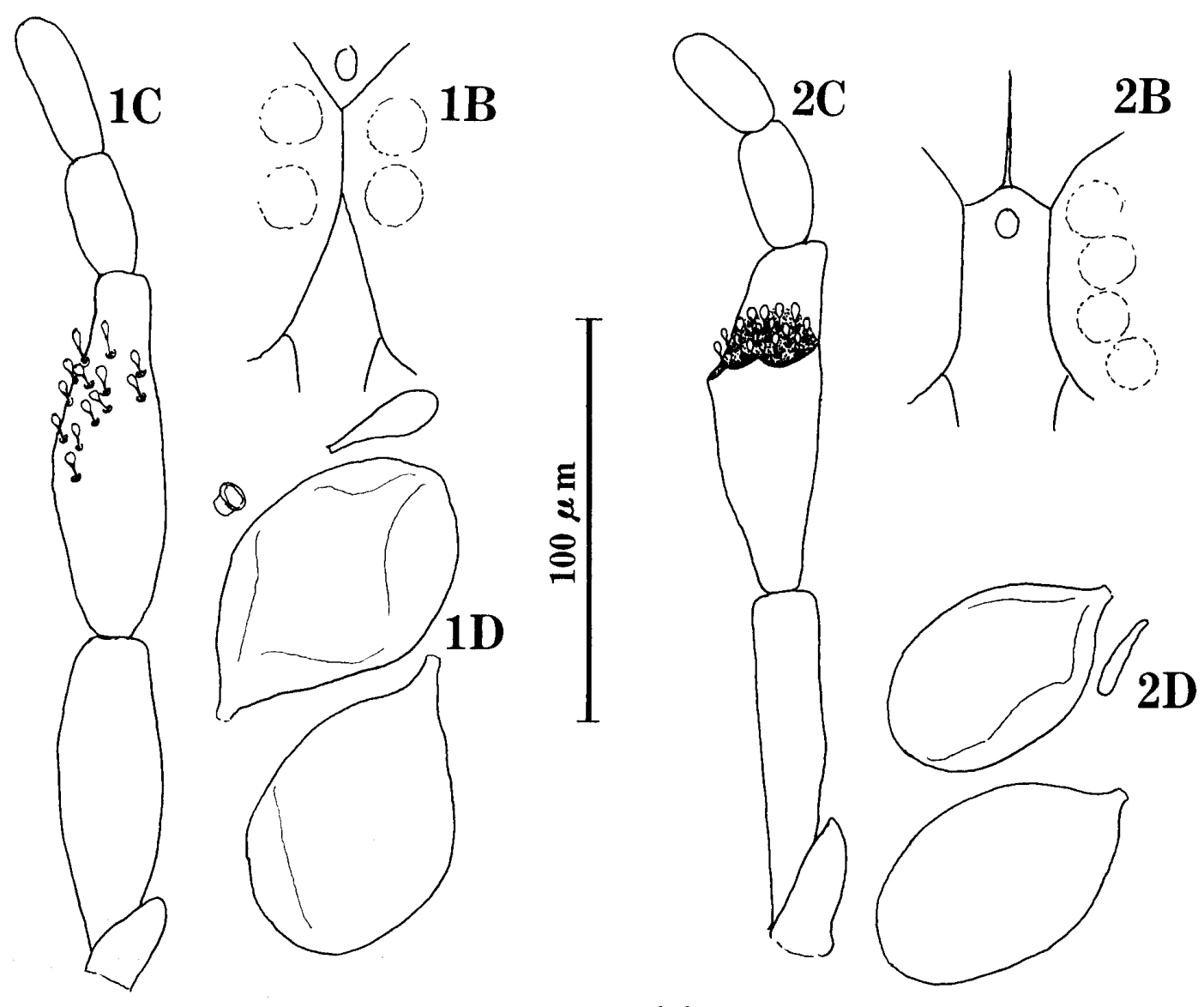

Figs. 1 and 2 
comb with 6 spines, with the second longest.

Wing (Fig. 1A): Length 1.24 and 1.40 $\mathrm{mm}, \mathrm{CR}$ 0.66. Pattern as figured, color dark with defined pattern of round pale spots; base of wing pale at nearly a third to $r-m$ crossvein; large pale spot over $r-m$ crossvein extending from costal margin to slightly behind media; large pale spot covering distal two thirds of second radial cell, extending 0.8 way to vein $\mathrm{M} 1$, midportion of vein M2 embraced by a pair of oval pale spots in cells M1 and M2, distal pale spots in cell M1 and M2 round, a similar pale spot in cell M4; a large spot in space between medial and mediocubital fork in cell M2, a pale streak connecting this spot narrowly with basal pale area of wing; anal cell with two round spots. Macrotrichia very scanty on distal fifth of wing. Halter pale brown.

Abdomen: Brownish. Spermathecae (Fig. 1D) pigmented, ovoid, tapering obliquely to short slender necks, subequal 80 by 50 and 80 by 48 ; large rudimentary spermatheca and ring present.

Holotype. One female, 1 September 1986, Higashidori-mura, Aomori, C. Tatebe.

Paratype. One female, 20 August 1987, Higashidori-mura, Aomori, C. Tatebe.

Discussion. The wing pattern of $C$. aomoriensis sp. $\mathrm{n}$. is characteristic of the known species belonging to the subgenus Culicoides or Hoffmania in the Oriental, Afrotropical, Palaearctic and Nearctic faunas in lacking the distal pale spot in cell R5.

\section{Culicoides tatebeae sp. $n$.}

Female (Fig. 2A-D).

Body: Medium-sized, dark brown.

Head: Eyes separated about two facets, with fronto-vertex suture, bare (Fig. 2A). Antenna with flagellar segments in proportion of 46-28-30-32-34-34-34-34-48-48-54-5480 , total length $513(420-562, n=13)$, AR $1.03(0.96-1.08, n=13)$, mean number of sensilla coeloconica $3.0,0.1,0.2,0.5,1.0,1.0$, $1.0,1.0,1.1,1.1,1.2,1.7,1.1$. Palpal seg- ments (Fig. 2B) in proportion of 34-80-8234-30, PR 2.9; third segment slender, with sensilla on slightly depressed area. Proboscis moderately long, $\mathrm{P} / \mathrm{H}$ ratio 0.81 (0.75-0.87, $n=13$ ) ; mandible with 14 to 16 teeth.

Thorax: Dark brown, mesonotum without prominent pattern, scutellum with a pair each of midscutellar and lateral bristles. Legs: Brown, fore tibia pale; hind tibial comb with 4 spines, with the second longest.

Wing (Fig. 2A) : Length 1.30 (1.16-1.36, $n=13) \mathrm{mm}$, GR 0.59. Pattern as figured, spots very vague, first over $r-m$ crossvein and second on anterior margin to base of wing. Macrotrichia numerous, extending to base of cell M2 and anal cell. Halter infuscated.

Abdomen: Brown. Spermathecae pigmented, oval with moderately long necks, subequal 72 by 42 and 66 by 40 ; long rudimentary spermatheca present, ring absent.

Holotype. One female, 4 June 1987, Higashidori-mura, Aomori, C. Tatebe.

Paratypes. Eleven females, 4 June 1987; 1 female, 2 July 1987, Higashidori-mura, Aomori, C. Tatebe.

Discussion. C. tatebeae sp. n. can be easily separated from other Japanese species by the general morphological characters, except for C. fukudai Wada which was described recently from the specimens collected in the same prefecture. C. tatebeae can be distinguished from $C$. fukudai by the larger values in $A R, P R$ and the number of mandibular teeth.

\section{Acknowledgements}

The author wishes to express his thanks to Dr. Y. Wada, Institute of Tropical Medicine, Nagasaki University for critical comments and Dr. C. Tatebe, Aomori Prefectural Mutsu Livestock Hygiene Service Center for providing with interesting specimens.

\section{REFERENCES}

Okada, T. (1941): Biting midges collected from northeastern district of Honshu, Japan. J. Coll.

Fig. 1 Culicoides aomoriensis sp. n.

Female. A, wing; B, fronto-vertex; C, palpus; D, spermathecae.

Fig. 2 Culicoides tatebeae sp. n.

Female. A, wing; B, fronto-vertex; C, palpus; D, spermathecae. 
Agric., Tokyo Imper. Univ., 15: 13-31.

Tatebe, C., S. Yamaguchi, K. Ohta, T. Sugawara, S. Tsukuda, A. Matsumoto, S. Yoshida and H. Sohma (1989): Identification of biting midges (Culicoides) and their distribution in Aomori Prefecture. J. Jpn. Vet. Med. Assoc., 42: 331337 (in Japanese with English summary).

Wada, Y. (1990): The verbosus group of the genus Culicoides Latreille (Diptera: Ceratopogonidae) in Japan, with descriptions of three new species and one hitherto unknown male. Trop. Med., 23: 49-72.

\begin{abstract}
摘 要
本州北端のヌカカ科 Culicoides 属の 2 新種

下北半島先端で Culicoides 属の 新種を 2 種記録し た. アオモリヌカカ C. aomoriensis は, R5 室に先 明斑を欠く特異な種である. タテベヌカカ $C$. tatebeae は青森県下で記録されている $C$. fukudai Wada にごく近似するが, より大きな AR 比, PR 比, 大顎 歯数を有する点で容易に区別される.
\end{abstract}

